\title{
ТЕОРЕТИЧНІ ПІДХОДИ ДО ВИЗНАЧЕННЯ ПОНЯТТЯ ПУБЛІЧНЕ УПРАВЛІННЯ
}

\author{
Славкова Олена Павлівна \\ доктор економічних наук, профресор \\ Сумський національний аграрний університет (м.Суми, Україна) \\ ORCID:0000-0002-1864-0810 \\ olena.slavkova.snau@gmail.com
}

Соколов Микола Олександрович

доктор економічних наук, професор

Сумський національний аграрний університет (м.Суми, Україна)

ORCID:0000-0002-1907-9041

sokolovnikolay55@gmail.com

\begin{abstract}
Дослідженнями встановлено, що в сучасних умовах все більшого значення набуває публічний сектор економіки та державне управління. Публічне управління це аналіз та розробка політики в державному та приватному секторах та робота в публічному секторі, яка повинна розглядатися як покликання служити своєму народу. Відповідно до мети даного дослідження дано визначення основних підходів до дефрініції публічного адміністрування, проаналізовано відповідність визначення деррініції до умов глобалізації та сучасного рівня розвитку суспільства та державотворення. Огляд багатьох публікацій та тенденції законодавства сьогодення дозволяють нам виділити основні точки зору на цінності, орієнтири ma cymність new public management. Публічне управління в даній роботі розглянуто з декількох точок зору, на основі огляду зарубіжної та вітчизняної літератури. В ході досліджень ми дійшли висновку що ще поняття неоднозначне та потребує подальших досліджень в зв'язку з тим, що розуміння суті такого явища як публічне управління та підходів до його розвитку безпосередньо впливає на державотворення та соціально-економічний розвиток.
\end{abstract}

Ключові слова:публічне управління, теорія публічного управління, питання адміністрації, теорія організації, державне управління, адміністративна теорія.

DOI: https://doi.org/10.32845/bsnau.2019.1.14

Постановка проблеми в загальному вигляді. Для багатьох людей держава сприймається як місце, де вони живуть і працюють, де розташований їх дім та сім'я, де підтримуються та розвиваються умови, що враховують етнокультурні особливості, там, де $є$ інститути та інституції, органи державної влади та партії, армія та поліція, межі і загальна для всіх мова, сільське господарство та промисловість, фінанси та багато іншого, що забезпечує умови життя людини. Тому розгляд питання щодо дефініції поняття «публічного управління» $€$ важливим бо $є$ складовою держави. Впродовж останніх років визначення публічного управління та його законодавче врегулювання привертає велику увагу науковців. Серед головних проблем, які викликають дискусію та занепокоєння, можна виділити: конституціоналізація державного управління, делегування законодавства та адміністративний розсуд, а також активізація участі судових органів у публічному управлінні та в реалізації програм та реформ (C. Kurt Zorn, 1998) .

Публічне управління як форма мислення та сфера вивчення змінюється від парадигми, в якій домінує політологія, до еклектичного масиву теоретичних внесків усіх суспільних наук, зокрема економіки. Основні базові знання з економіки $€$ важливим для ефективного сучасного публічного управління, тому що без фундаментального розуміння економіки можна зробити багато помилок в політиці.

В сучасних умовах все більшого значення набуває публічний сектор економіки та державне управління. Публічне управління це аналіз та розробка політики в державному та приватному секторах та робота в публічному секторі, яка повинна розглядатися як покликання служити своєму народу.

Аналіз останніх досліджень і публікацій. Дослідженню питань визначення поняття публічного управління присвятили свої наукові праці такі зарубіжні вчені: Aderibigbe A., John O., John O. (2014), Dunleavy P., Hood C. (1994), Jackson M., Hood C. (1991), Martin D. (1993), Merkus S., Veenswijk, M. B. (2017), Muhammad N. A. (2015), Norbutus D. K., Norbutus T. J. (2013), Perez A. (1993), Stever J. A. (1993), Stout M. (2006), Ugyel L. (2017), Zorn K. C. (1998), та інші. Питання розвитку публічного управління заходяться під увагою не тільки економістів а й політологів, психологів та соціологів. Незважаючи на різні напрямки досліджень дане питання настільки багатогранне, що потребує постійної уваги, особливо в період реформування публічної влади.

Формулювання цілей статті. Метою статті $€$ визначення основних підходів до дефініції публічне управління, проведення їх оцінки, аналіз відповідності до умов глобалізації, сучасного рівня розвитку суспільства та державотворення.

Методи дослідження. У дослідженні було використано такі методи дослідження як: метод аналізу, метод порівняння, емпіричний метод наукового дослідження та метод логічного узагальнення. За їх допомогою було проаналізовано основні визначення поняття «публічне управління» в працях зарубіжних та українських науковців.

Виклад основного матеріалу дослідження. Перші спроби вивести окреме поняття «публічне управління» було зроблено Вудро Вілсоном (1887) у своїй праці «Наука про державне управління». В 1887 р. він вперше ввів поняття «публічне управління» (public governance) та «публічна адміністрація» (public administration). Public administration традиційно розуміється як діяльність, що характеризується як 
мистецтво та наука управління громадськими справами, при цьому особлива увага приділяється питанням роботи 3 людьми, комерційними, некомерційними, фінансовими організаціями та домогосподарствами на основі пріоритетів встановлених законами, правилами та процедурами. Поняття державного управління включає також функції виконавчих органів державної влади (Nisar, Muhammad A., 2015).

Деякі автори розглядають державне (публічне) управління у нерозривному зв'язку з глобалізаційними проблемами через принципи економічної теорії. Визначаючи публічне управління вони вважають, що чисельність уряду в процесі розвитку рідко зменшується, а влада може зруйнуватися якщо, з одного боку, не вона буде шукати глобальні суспільні блага, а з іншого - виступати за збільшення місцевих суспільних благ та проведення процедури децентралізації (Diane K. Norbutus, Thomas J. Norbutus, 2013).

у 1980-х рр. у відповідь на зміни в розвитку глобальної соціально-економічної системи замінився традиційний підхід державного управління та почала розвиватися ідеологія публічного управління. Нова модель управління державою повинна ґрунтуватися на методах управління, організаційних ідеях та цінностях, що використовується в сучасному бізнесі, з метою підвищення ефективності та якості послуг у державному секторі а також враховувати роль громадян як отримувачів послуг або клієнтів у публічному секторі (Merkus S.,Veenswijk M. B., 2017).

На думку Адеяре Адерібигбле, Джона Олла та Джона Олувафеми (Adejare Aderibigbe, Olla, John, Oluwafemi John, 2014) публічне управління - це динамічна сила, визначення якої не до кінця набуло свого остаточного визначення. Державне управління розглядається авторами як діяльність уряду на федеральному, державному та місцевому рівнях.

Цікавими є дослідження Маргарет Стоун, яке вона оприлюднила на конференції наукових дослідників з питань надзвичайних ситуацій у грудні 2005 року в місті Даллас штат Tехас: «Що таке публічне управління?». В своєму виступі вона досліджує публічне управління з точки зору значення самурая як державного службовця та значення родинності в єдиноборствах як аналогію традиціям в теорії публічного управління. Автором ставиться під сумнів виділення термінів традиційного та пострадиційного в теорії публічного управління та наголошується на усвідомленні, як теорія формує наші дії, і необхідно бути уважними до свого вибору (Margaret Stout, 2006).

Розглядаючи еволюцію поняття публічне управління можна виділити також виникнення терміну New Public Management («новий державний менеджмент»), який був введений вченими з Великобританії та Австралії Михаелем Джексоном та Кристофером Холдом у 1991 році (Jackson Michael, Hood Christopher, 1991).

Подальші дискусії та обговорення породили різноманітні значення цього терміна. Одні вчені визнають термін новий державний менеджмент як впровадження нової інституціональної економіки, державного управління, а інші використовують для цього позначення зміни в політиці.

Андрес Перес (1993) стверджує, що публічне управління вивчає взаємозв'язки між елементами адміністративної держави та між адміністративною державою та її середовищем, відмежованими від часу та дискутує з іншими авторами які вважають, що історична спрямованість розвитку поняття публічного адміністрування знижає здатність до побудови теорії державного управління (Andres Perez, 1993).

Вивчаючи характер ретроспектив літературних джерел з питань державного управління Даніель Мартін (1993) визначає, що в останні роки він змінився від ввічливого поваги державного управління до сучасного розуміння даного поняття. На думку автора більш старша література може вирішити деякі з найактуальніших сучасних проблем в публічному управлінні. А сучасні праці часто характеризуються відсутністю фундаментальних цілей або морального спрямування в публічному управлінні (Daniel Martin, 1993).

Заслуговують на увагу питання історичної ретроспективи описані Джеймсом Стевером (1993). Виходячи з його досліджень починаючи з 1920-х років група теоретиків зробила істотний відхід від прогресивної адміністративної теорії. Постпрогресисти стверджували, що публічні організації повинні бути більш ніж ефективними виробниками; вони повинні бути інститутами, в межах яких люди можуть розвивати свій творчий потенціал. 3 цією метою вони пропагували єдину науку про організацію та управління. Така теорія й сьогодні має право на існування в зв'язку з тим, що відсутність між ефективністю та орієнтованими на людину публічними організаціями веде до ризику впливу не лише життєздатності сучасних публічних організацій, але й на курс сучасності (James A. Stever, 1993).

На формування поняття публічне управління великий вплив мала політологія, де було сформовано витоки цього напрямку. Навіть на сьогодні вплив політології на публічне управління все ще очевидний, тому що численні програми державного управління базуються на постулатах політології; велика кількість викладачів програм публічного управління політологи за освітою та професійні товариства та наукові видання 3 публічної адміністрації очолюють політологи (C. Kurt Zorn, 1998).

Важливу роль економіки в публічному управління підтверджує Курт Зорн (1998). В своїй статті він обговорює яку роль економіка може та повинна відігравати в публічному управлінні, по-перше це взаємозв'язок між державним управлінням та економікою; по-друге, недоліки економічної політики не дадуть їй стати невід'ємною складовою державної політики; по-третє, необхідно знаходити шляхи кращого поєднання економіки з розробкою державної політики (C. Kurt Zorn, 1998).

Деякі автори обговорюють ідею «нового публічного управління» у світлі попередніх зусиль управлінської реформи, стверджуючи, що вона виявився досить міцним та послідовним планом. Серед викликів перед публічними управлінням вони виділяють наступні: перспектива результатів поза межами загальноприйнятого розрізнення традиційних та сучасних стилів публічного управління, ризик неналежного копіювання; квазіконституційні питання щодо основних компетенцій органів публічного сектору (Patrick Dunleavy, Christopher Hood, 1994).

Продовжуючи огляд необхідно звернути увагу на політично-адміністративну дихотомію, яка давно була предметом значних дискусій у публічному управлінні. Так Лхаванг Угель (2017) вважає, що незважаючи на те, що між політикою та адміністрацією немає чіткого розмежування, напруга між ними продовжує залишатися значною. Автор наголошує, що країни 3 різним законодавством прагнуть підтримувати політичний нейтралітет в управлінні та обмежувати політичну участь державних службовців. Важливо, що динаміка та 
складність у формуванні відповідного балансу між політикою та адміністрацією значно відрізняються від однієї системи до іншої (Lhawang Ugyel, 2017).

Аналізуючи різні думки стосовно поняття публічного управління необхідно виділити думку Кошелевой Л. про те що удосконалення системи публічного адміністрування забезпечить утвердження України як розвиненої, правової, цивілізованої, конкурентоспроможної європейської держави з високим рівнем життя, соціальних стандартів та демократії. Автор пише, що враховуючи демократичну практику сучасних держав, найбільш доцільним є застосування ліберально-комунітаристського підходу, який забезпечить ефективність в управлінні системи органів публічної влади (Кошелева Л., 2018).

Огляд багатьох публікацій та тенденції законодавства сьогодення дозволяють нам виділити основні точки зору на цінності, орієнтири та сутність нової new public management.
Перше це перехід від стандартних форм обслуговування до більш гнучких і різних. Друге термін «публічне управління» активно використовується в засобах масової інформації, наукових публікаціях, законодавчих актах та інше. Це поняття часто перекликається 3 «державним управлінням», але набуває іншого значення.

Висновки. Підводячи підсумок проведеного дослідження необхідно зазначити, що публічне управління в даній роботі розглянуто з декількох точок зору, на основі огляду зарубіжної та вітчизняної літератури. В ході досліджень ми дійшли висновку що це поняття неоднозначне та потребує подальших досліджень в зв'язку з тим, що розуміння суті такого явища як публічне управління та підходів до його розвитку безпосередньо впливає на державотворення та соціально-економічний розвиток держави.

\section{Список літератури:}

1. Zorn K. C. (1998). The economic perspective on public administration. International Journal of Public Administration, Volume 21. Issue 6-8. P.1119-1136.

2. Aderibigbe A., John O., John O. (2014). Towards A Theoretical Definition of Public Administration. Journal of Management. Volume 16. P.65-70.

3. Dunleavy P., Hood C. (1994). From old public administration to new public management. Public Money and Management. Volume 14. Issue 3. P.9-16.

4. Jackson M., Hood C. (1991). The New Public Management: A Recipe for Disaster? Canberra Bulletin of Public Administration. Volume 64. P. 12-17.

5. Daniel Martin (1993). Foundations of public administration: Introduction to the symposium. International Journal of Public Administration. Volume 16. Issue 2. P. xi-xiv

6. Merkus, S., Veenswijk, M. B. (2017). Turning New Public Management theory into reality: Per formative struggle during a large scale planning process. Environment and Planning C. Government and Policy. №35(7). P. 1264-1284.

7. Muhammad N. A. (2015). Practitioner Envy and Construction of the Other in Public Administration. Administration and Society. № 49 (10). P. 1403-1423.

8. Norbutus D. K., Norbutus T. J. (2013). Leadership in Complex Situations. Managing and Engineering in Complex Situations,

9. Perez A. (1993). Historical change and the administrative state: An analysis of the theoretical foundations of public administration. International Journal of Public Administration. Volume 16. Issue 2. P. 261-293.

10. Stever J. A. (1993). Modernism, administration, and the post-progressive era. International Journal of Public Administration. Volume 16. Issue 2. P.237-259.

11. Stout M. (2006) A Samurai's Lineage: Theoretical Traditions in Public Administration. Administrative Theory and Praxis. Volume 28. Issue 4. P. 618-630.

12. Ugyel L. (2017). Relationship between politics and administration: a comparative analysis of legislation and governance in Pacific Island government alsystems. Asia Pacific Journal of Public Administration. Volume 39. Issue 3. P.153-162.

13. Кошелева Л. (2018). Основні теоретичні підходи до визначення публічного адміністрування. Державне управління та місцеве самоврядування. № 2(37). С.13-19.

Olena Slavkova, Dr, professor, Sumy National Agrarian University (Sumy, Ukraine)

Nikolay Sokolov, Dr, professor, Sumy National Agrarian University (Sumy, Ukraine)

Theoretical approaches to definition of public administration

Public administration is defined as a form of thinking and a field of study that changes from a paradigm dominated by political science to an eclectic array of theoretical contributions of all social sciences, including economics, philosophy, sociology, management and others. Basic knowledge of economics is important for effective modern public administration, because without a fundamental understanding of the economy, many mistakes can be made in politics.

This research has shown that the public sector of economy and public administration are becoming increasingly important within current environment. Public administration is the analysis and development of policies within public and private sectors, as well as activities of the public sector, which should be seen as a mission to serve its people.

In accordance with the purpose of this research, main approaches to the definition of public administration were defined; correspondence of this definition to the conditions of globalization and current state of society and state-making were analyzed.

The review of many publications and latest trends of general law allow us to highlight main points of view on values, benchmarks and essence of new public management. Among the challenges of the development of public administration system are the 
following: the prospect of results beyond the conventional distinction between traditional and contemporary styles of public administration, the risk of improper copying, experience of other countries; quasi-constitutional issues regarding the core competencies of public sector bodies: main points of view on values and benchmarks in public administration - it is a transition from standard forms of service to more flexible and different ones. The use of the term "public administration" in the media, scientific publications, legislation, etc. is often related to "state administration", but it takes on a different meaning.

In terms of this research public administration is considered from several points of view, based on the review of foreign and domestic literature. As part of our research we have come to the conclusion that this concept is ambiguous and needs further analysis due to the fact that understanding of the essence of such a phenomenon as public management and approaches to its development directly influences state-making and socio-economic development.

Key words: public administration, public management issues, politic administration issues, organizational theory, public administration, administrative theory

Дата надходження до редакції: 14.01.2019 р. 